\title{
Developing Pre-Service Teachers' Technological Pedagogical Content Knowledge for Teaching Mathematics with the Geometer's Sketchpad through Lesson Study
}

\author{
Chew Cheng Meng ${ }^{1} \&$ Lim Chap Sam ${ }^{1}$ \\ ${ }^{1}$ School of Educational Studies, Universiti Sains Malaysia, Penang, Malaysia \\ Correspondence: Chew Cheng Meng, School of Educational Studies, Universiti Sains Malaysia, 11800 Penang, \\ Malaysia. Tel: 60-4-653-5100.E-mail: cmchew@usm.my
}

Received: April 24, 2012

Accepted: June 25, 2012

Online Published: January 9, 2013

doi:10.5539/jel.v2n1p1

URL: http://dx.doi.org/10.5539/jel.v2n1p1

\begin{abstract}
The purpose of this study was to develop pre-service secondary teachers' technological pedagogical content knowledge (TPACK) for teaching mathematics with The Geometer's Sketchpad (GSP) through Lesson Study (LS). Specifically, a single-group pretest-posttest design was employed to examine whether there was a significant difference in the pre-service secondary teachers' TPACK for teaching mathematics with GSP after engaging in LS which was incorporated into the mathematics teaching methods course during the first semester of the 2011/2012 academic session in a Malaysian public university. Forty-six pre-service secondary teachers who enrolled in the course completed both the pretest and posttest questionnaires on teachers' TPACK for teaching mathematics with GSP. The results of the paired-samples t-test indicated that there was a significant difference in the pre-service secondary teachers' TPACK for teaching mathematics with GSP for all the subscales after engaging in LS.
\end{abstract}

Keywords: TPACK, the Geometer's sketchpad, lesson study, pre-service teachers, secondary mathematics

\section{Introduction}

\subsection{Background of the Study}

GSP is a type of dynamic geometry software for constructing and investigating mathematical objects, not just in geometry. For example, in Algebra, students can use GSP to investigate gradients and equations of straight lines, properties of parabolas, and many other important Algebra topics. In Statistics, students can employ GSP to investigate concepts of mean, standard deviation and variance. In Trigonometry, GSP can be used to investigate trigonometric functions (Chanan, 2000). In addition, according to Finzer and Jackiw (1998, p. 2), GSP "can best foster mathematical inquiry and learning through 'dynamic manipulation' experiments." This is because students can directly manipulate mathematical objects represented on the screen and the mathematical objects stay coherent and whole at all times as they are dragged. Besides, students feel that they are involved with the objects they are manipulating and they can focus on how to achieve their mathematical goals, instead of how to use GSP.

In fact, research has shown that teaching mathematics with GSP enhances students' learning of plane geometry (e.g., Choi, 1996; Driskell, 2004; Thompson, 2006; Chew \& Lim, 2010) and solid geometry (e.g., July, 2001; McClintock et al., 2002; Chew, 2007). Furthermore, teaching mathematics with GSP which is "based on experimentation, observation, data recording and conjecturing" (Olive, 2000, p. 3) encourages "a process of discovery that more closely reflects the way mathematics is invented" (Bennett, 1999, p. viii). This inquiry-based approach to teaching mathematics with GSP should "give students the opportunity to engage in mathematics as mathematicians, not merely as passive recipients of others mathematical knowledge" (Olive, 2000, pp. 3-4).

In view of its importance, the Ministry of Education Malaysia advocates the use of GSP in the teaching and learning of mathematics (Ministry of Education Malaysia, 2003). However, a brief survey study conducted by Kasmawati (2006) on 151 secondary mathematics teachers in the state of Penang showed that $26 \%$ of the teachers had attended GSP training courses but only $2 \%$ had used GSP to teach mathematics in the classroom. The two main reasons given by the mathematics teachers were lack of skills and confidence as well as lack of time to prepare a GSP sketch to use GSP to teach mathematics in the classroom. 
In order for teachers to effectively use technology in their teaching, they need to develop TPACK for teaching with the technology (Neiss, 2005). Mishra and Koehler (2006) conceptualized TPACK as the integration of teachers' knowledge of content, pedagogy and technology and it is needed to effectively use technology to teach specific subject matter. More specifically, Shafer (2008) showed that teachers need TPACK for teaching mathematics with GSP in order to effectively plan and implement a GSP lesson in the classroom.

Hence, there is an urgent need to develop pre-service secondary teachers' TPACK for teaching mathematics with GSP so that they can effectively use GSP to teach mathematics in the classroom as advocated by the Ministry of Education Malaysia. But to develop TPACK for teaching mathematics with GSP, they need guidance, help and support (Shafer, 2008). One potential way to achieve this is through LS which is a Japanese model of teacher professional development that teachers engage in to improve the quality of their teaching as well as to enrich students' learning experiences. More specifically, LS is a process by which small groups of teachers meet at stipulated time to plan lessons, observe these lessons unfold in actual classrooms, discuss their observations and to revise the lesson plans collaboratively. Basically, LS comprises six main steps: (1) collaboratively planning the lesson plan, (2) seeing the lesson plan in action, (3) discussing the lesson plan, (4) revising the lesson plan, (5) teaching the new version of the lesson, and (6) sharing reflections about the new version of the lesson (Fernandez \& Yoshida, 2004).

A substantial amount of research studies have shown that LS improves teachers' learning and supports teachers to grow professionally (e.g., Stigler \& Hiebert, 1997; Shimahara, 1998; Lewis \& Tsuchida, 1998; Stigler \& Hiebert, 1999; Yoshida, 1999; Fernandez, \& Yoshida, 2004; Lim, White \& Chiew, 2005). In addition, research has also shown that LS is a worthwhile and beneficial learning experience for pre-service teachers. Chiew and Lim (2003) conducted a LS with five pre-service mathematics teachers while they were undergoing their teaching practice in school. Their findings showed that LS helped improve the pre-service mathematics teachers' content knowledge and enhance their confidence to teach the lesson, and they gained much more diverse teaching ideas that helped them improve their pedagogical content knowledge. Moreover, Fernandez and Robinson (2006) identified three main categories as central to the pre-service teachers' learning through microteaching and LS, namely connecting theory and practice, collaboration, and reflection. The pre-service teachers reported that the opportunity to apply in practice what they were learning in theory was highly valuable. They valued the sharing of different points of view and understandings about teaching mathematics as well as the feedback contributed by group members which helped them to think differently about teaching mathematics. They also began to understand the importance of reflection throughout the planning, teaching and revising steps of LS.

\subsection{Purpose of the Study}

In Malaysia, there has been a lack of research that specifically examines if pre-service secondary teachers' TPACK for teaching mathematics with GSP could be developed through LS. Therefore, the purpose of this study was to develop pre-service secondary teachers' TPACK for teaching mathematics with GSP through LS. More specifically, this study aimed to examine whether there was a significant difference in the pre-service secondary teachers' TPACK for teaching mathematics with GSP after engaging in LS which was incorporated into the mathematics teaching methods course during the first semester of the 2011/2012 academic session in a Malaysian public university.

\subsection{Theoretical Framework}

The TPACK framework, which builds on Shulman's Pedagogical Content Knowledge, describes the relationships between three basic components of teachers' knowledge namely Content Knowledge (CK), Pedagogical Knowledge (PK), and Technological Knowledge (TK) required for effective integration of technology in teaching and learning (Schmidt et al., 2009) as shown in Figure 1.

According to Schmidt et al. (2009, p.125), CK refers to the knowledge about actual subject matter that is to be learned or taught and how the nature of knowledge is different for various content areas. PK refers to the knowledge about the methods and processes of teaching and includes knowledge in classroom management, assessment, lesson plan development, and student learning. TK refers to the knowledge about various technologies, ranging from low-tech technologies such as pencil and paper to digital technologies such as the Internet, digital video, interactive whiteboards, and software programs.

In this framework, the interactions among these components of knowledge are equally important which are represented as Pedagogical Content Knowledge (PCK), Technological Content Knowledge (TCK), Technological Pedagogical Knowledge (TPK), and Technological Pedagogical Content Knowledge (TPACK). According to Schmidt et al. (2009, p.125), PCK refers to the content knowledge that deals with the teaching 
process (Shulman, 1986) and it is different for various content areas. TCK refers to the knowledge of how technology can create new representations for specific content and how teachers can change the way students practise and understand concepts in a specific content area by using a specific technology. TPK refers to the knowledge of how various technologies can be used in teaching and changing the way teachers teach by using the technologies. Lastly, TPACK refers to the knowledge required by teachers for effectively integrating technology into their teaching in any content area by teaching the content using appropriate pedagogical methods and technologies.

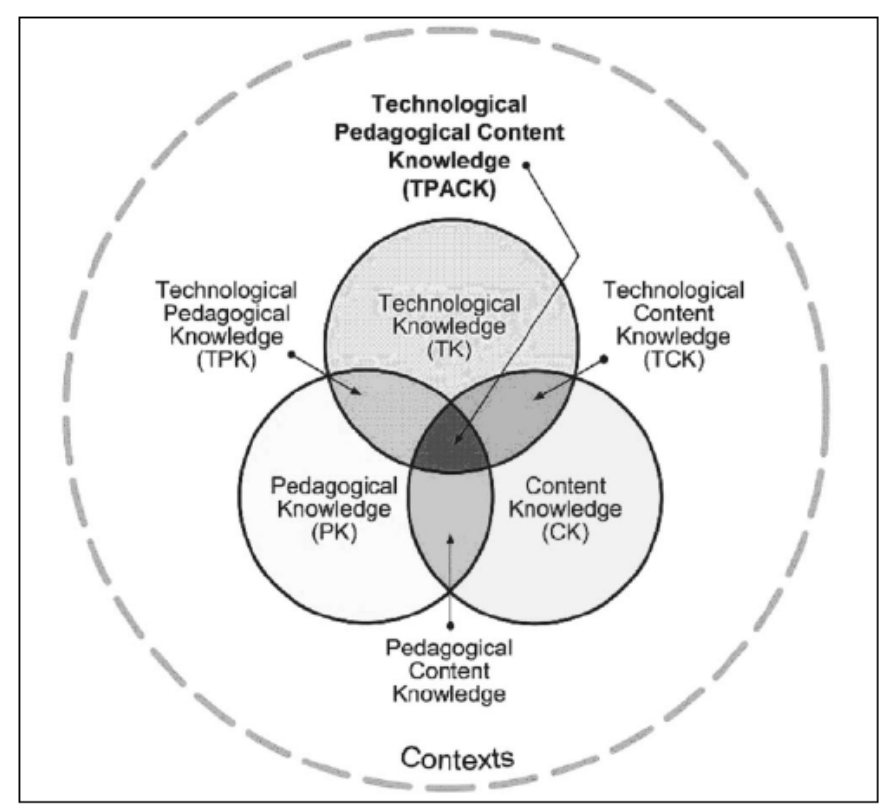

Figure 1. The TPACK framework (Source: Schmidt et al., 2009, p. 124)

\section{Method}

\subsection{Research Design and Participants}

A one-group pretest-posttest design (Campbell \& Stanley, 1963) was employed to examine whether there was a significant difference in the pre-service secondary teachers' TPACK for teaching mathematics with GSP after engaging in LS which was incorporated into the mathematics teaching methods course. The participants of this study consisted of 46 pre-service secondary teachers who enrolled in the mathematics teaching methods course in the first semester of the academic session 2011/2012 in a Malaysian public university.

\subsection{Instrument}

A Survey of Pre-service Secondary Teachers' TPACK for Teaching Mathematics with GSP was used to assess the participants' TPACK for teaching mathematics with GSP before and after engaging in LS. The questionnaire was adapted from the Survey of Teachers' Knowledge of Teaching and Technology (Schmidt et al., 2009). It contained several demographic questions (such as ethnicity, gender, age, bachelor programme and area of specialization) and seven subscales with 47 self-report items that assessed the participants' TPACK for teaching mathematics with GSP. All the items used a five point Likert scale to rate the extent to which the participants strongly disagreed, disagreed, neither agreed or disagreed, agreed, or strongly agreed with statements about TPACK for teaching mathematics with GSP.

Algebra, Geometry, Statistics and Trigonometry were of particular interests in this study because most of the topics in the Form One (the first year of secondary school) to Form Five (the fifth year of secondary school) Malaysian Mathematics syllabus are in these four content areas. As such, the four subscales of Content Knowledge in the Survey of Teachers' Knowledge of Teaching and Technology (Schmidt et al., 2009) namely Mathematics, Literacy, Science, and Social Science were changed to Algebra, Geometry, Statistics and Trigonometry, respectively in the adapted questionnaire. In addition, any words related to technology were 
changed to GSP because this study only focused on the use of one specific technology (that is GSP) in the teaching and learning of the topics of Algebra, Geometry, Statistics and Trigonometry.

Each item response was scored with a value of 1 for strongly disagree, 2 for disagree, 3 for neither agree or disagree, 4 for agree and 5 for strongly agree. For each subscale the participant's responses were averaged. For example, the 7 questions under TK are averaged to produce one TK score (Schmidt et al., 2009). Before conducting the paired-samples $t$-tests, the reliability for each subscale was computed using the pre-survey data. Cronbach's alpha coefficients for each sub-scale ranged from .77 to .80 (see Table 1).

Table 1. Summary of Cronbach's alpha coefficients for each subscale

\begin{tabular}{lc}
\hline Subscale & Cronbach's alpha \\
\hline Technological Knowledge (TK) & .79 \\
Content Knowledge (CK) & .77 \\
$\quad$ Algebra & .78 \\
$\quad$ Geometry & .78 \\
$\quad$ Statistics & .78 \\
$\quad$ Trigonometry & .78 \\
Pedagogical Knowledge (PK) & .79 \\
Pedagogical Content Knowledge PCK) & .80 \\
Technological Content Knowledge (TCK) & .80 \\
Technological Pedagogical Knowledge (TPK) & .79 \\
Technological Pedagogical Content Knowledge (TPACK) & .79 \\
Overall TPACK & .80 \\
\hline
\end{tabular}

\subsection{Procedure}

In the first two-hour lecture the coordinator of the course (the researcher) explained to all the participants the outline of the course, the coursework (that is, a review of a journal article on teaching mathematics with GSP for each participant, a lesson plan for teaching mathematics with GSP for each pair of participants, and individual simulated teaching of the planned lesson for each participant), Mishra and Koehler's (2006) TPACK framework, Fernandez and Yoshida's (2004) LS process as well as the research procedure. Next, the Survey of Pre-service Secondary Teachers' TPACK for Teaching Mathematics with GSP was administered to all the 46 participants. At the end of the lecture, the participants were divided into four tutorial groups. Each tutorial group met at a specific tutorial time for one hour every week. The researcher conducted two GSP workshops during the first two tutorials for each tutorial group. The aim of the first GSP workshop was to explain the functions of the Title bar, Menu bar, Sketch plane, and Toolbox of GSP as well as how to use the basic tools of GSP (that is Selection Arrow Tool, Point Tool, Compass Tool, Straightedge Tool, Text Tool, and Custom Tool) to construct mathematical objects such as points, segments, rays, lines, circles, and polygons. The aim of the second GSP workshop was to design GSP activities for teaching Form One to Form Five Mathematics. After the workshops, the six main steps of LS were implemented as follows:

Step 1 (Collaboratively Planning the Lesson Plan): During the third tutorial, the participants in each tutorial group were allowed to form their own LS groups with each LS group comprising two participants. Thus, twenty-three LS groups were formed in this study with six LS groups (known as LS Group 1 to LS Group 6) in the first three tutorial groups and five LS groups (known as LS Group 1 to LS Group 5) in the fourth tutorial group. Each LS group was allowed to choose a topic in Algebra, Geometry, Statistics or Trigonometry from the Form One to Form Five Mathematics syllabus. Then, each LS group discussed and planned collaboratively a 40-minute lesson plan for teaching the chosen topic with GSP. Finally, each LS group planned a schedule for the subsequent meeting(s) to complete their lesson plan, GSP sketches and activity sheets before the fourth tutorial.

Step 2 (Seeing the Lesson Plan in Action): During the fourth tutorial, one participant from LS Group 1 in each tutorial group taught the 40-minute lesson as planned to their peers in the Mathematics Teaching Room. The lesson was observed by his/her partner of LS Group 1 and the researcher using the lesson plan, GSP sketches and activity sheets to guide their observations. The lesson was videotaped using a video-recorder which was placed 
stationary at the back of the room.

Step 3 (Discussing the Lesson Plan): After the lesson, the peers and the researcher provided comments and suggestions to improve the lesson plan, GSP sketches and activity sheets. The discussion was also videotaped using the same video-recorder.

Step 4 (Revising the Lesson Plan): After the tutorial, the members of LS Group 1 in each tutorial group planned a schedule for the subsequent meeting(s) to revise their lesson plan, GSP sketches and activity sheets based on their peers' as well as the researcher's comments and suggestions before the fifth tutorial. The end product of this step would be a revised lesson plan, GSP sketches and activity sheets.

Step 5 (Teaching the New Version of the Lesson): The new version of the lesson based on the revised lesson plan, GSP sketches and activity sheets was then taught by the other partner of LS Group 1 in the other tutorial group to different peers in the Mathematics Teaching Room during the fifth tutorial. The lesson was observed by his/her partner of LS Group 1 (who had taught the first lesson) and the researcher using the revised lesson plan, GSP sketches and activity sheets to guide their observations. The lesson was also videotaped using the same video-recorder. After the lesson, the peers and the researcher provided comments and suggestions to further improve the lesson plan, GSP sketches and activity sheets. The discussion was also videotaped using the same video-recorder.

Step 6 (Sharing Reflections about the New Version of the Lesson): After the tutorial, the members of LS Group 1 in each tutorial group planned a schedule for the subsequent meeting(s) to revise their lesson plan, GSP sketches and activity sheets for a second time based on their peers' as well as the researcher's comments and suggestions before the sixth tutorial. The end product of this step would be a final lesson plan, GSP sketches and activity sheets for submission as their coursework during the sixth tutorial. Steps 2 to 6 was repeated for LS Groups 2, 3, 4, 5 and 6 in the subsequent tutorials. During the last lecture, the Survey of Pre-service Secondary Teachers' TPACK for Teaching Mathematics with GSP was administered to all the 46 participants.

\section{Results}

Table 2 shows the results of the paired-samples t-test using SPSS version 19 for Windows. The mean scores for all the subscales and overall TPACK in the pre-survey were lower than the mean scores for all the subscales and overall TPACK in the post-survey. In addition, the differences between the mean scores were statistically significant for all the subscales and overall TPACK at $p<.05$, indicating that the pre-service secondary teachers' TPACK for teaching mathematics with GSP had improved significantly after engaging in LS. In addition, the differences between the mean scores were statistically significant for all the subscales of CK at $p<.05$ except for the subscale of Statistics $(p>.05)$, suggesting that the pre-service secondary teachers' CK for Algebra, Geometry and Trigonometry had improved significantly after engaging in LS except CK for Statistics.

Table 2. Results of the paired-samples t-test $(\mathrm{N}=46)$

\begin{tabular}{|c|c|c|c|c|c|c|c|}
\hline \multirow[b]{2}{*}{ Subscale } & \multicolumn{2}{|c|}{ Pre-survey } & \multicolumn{2}{|c|}{ Post-survey } & \multirow[b]{2}{*}{$t$} & \multirow[b]{2}{*}{$\mathrm{df}$} & \multirow[b]{2}{*}{$\begin{array}{l}\text { Sig. } \\
\text { (2-tailed) }\end{array}$} \\
\hline & Mean & $\begin{array}{l}\text { Standard } \\
\text { Deviation }\end{array}$ & Mean & $\begin{array}{l}\text { Standard } \\
\text { Deviation }\end{array}$ & & & \\
\hline TK & 2.01 & .68 & 3.65 & .51 & 3.16 & 45 & $.000^{*}$ \\
\hline CK & 3.62 & .58 & 3.81 & .42 & 2.65 & 45 & $.011^{*}$ \\
\hline Algebra & 3.64 & .65 & 3.85 & .48 & 2.53 & 45 & $.015^{*}$ \\
\hline Geometry & 3.64 & .61 & 3.86 & .48 & 2.47 & 45 & $.017^{*}$ \\
\hline Statistics & 3.58 & .65 & 3.73 & .51 & 1.87 & 45 & .068 \\
\hline Trigonometry & 3.62 & .67 & 3.78 & .52 & 2.26 & 45 & $.029 *$ \\
\hline PK & 3.30 & .65 & 3.89 & .47 & 6.40 & 45 & $.000 *$ \\
\hline PCK & 3.11 & .80 & 3.70 & .51 & 5.08 & 45 & $.000^{*}$ \\
\hline TCK & 1.92 & .79 & 3.82 & 1.22 & 8.50 & 45 & $.000^{*}$ \\
\hline TPK & 2.33 & .93 & 3.91 & .41 & 10.25 & 45 & $.000^{*}$ \\
\hline TPACK & 2.24 & .85 & 3.76 & .42 & 11.15 & 45 & $.000^{*}$ \\
\hline Overall TPACK & 2.65 & .49 & 3.79 & .42 & 13.54 & 45 & $.000^{*}$ \\
\hline
\end{tabular}

* significant at $\mathrm{p}<0.05$ 


\section{Discussion}

The results of this study suggested that LS could help the pre-service secondary teachers to develop their TPACK for teaching mathematics with GSP. Specifically, the pre-service secondary teachers' TK, CK, PK, PCK, TCK, TPK and TPACK had improved significantly after engaging in LS. These results are generally quite consistent with the results of previous studies on LS and pre-service teachers (e.g., Chiew \& Lim, 2003; Fernandez \& Robinson, 2006). Chiew and Lim (2003) found that LS helped improve the pre-service mathematics teachers' content knowledge and pedagogical content knowledge. In addition, Fernandez and Robinson (2006) found that the pre-service teachers valued the opportunity to apply in practice what they were learning in theory, the sharing of different points of view and understandings about teaching mathematics, as well as the feedback contributed by group members which helped them to think differently about teaching mathematics after engaging in LS. The results imply that incorporating LS into the mathematics teaching methods course could be a potential means of developing pre-service secondary teachers' TPACK for teaching mathematics with GSP because it provided them guidance, help and support when needed (Shafer, 2008).

However, the difference between the mean scores was not statistically significant for the subscale of Statistics under the CK component. One possible explanation was that no LS group happened to choose any topic in Statistics for the simulated teaching with GSP because all the LS groups randomly chose their topics from a box containing all the topics in Algebra, Geometry, Statistics and Trigonometry. Thus, it is suggested that in future studies all the LS groups in each tutorial group should randomly choose a topic from each content area (that is, four boxes with each box containing all the topics of each content area) for the simulated teaching with GSP.

In conclusion, we acknowledge our limitations in making any generalizations from the results of this study which used a one-group pretest-posttest design and self-report questionnaire. Nevertheless, the results of this study suggested for this sample that by incorporating LS into the mathematics teaching methods course, the pre-service secondary teachers' TPACK for teaching mathematics with GSP had improved significantly.

\section{Acknowledgements}

This project is made possible with funding from the Short Term Grant of University Sains Malaysia, Penang, Malaysia. The authors would like to thank the pre-service secondary teachers who voluntarily participated in this study.

\section{References}

Baynes, J. F. (1999). The development of a van Hiele-based summer geometry program and its impact on student van Hiele level and achievement in high school geometry. (Ed.D. Dissertation, Columbia University Teachers College, 1998). Dissertation Abstracts International, 59(07), 2403A. Retrieved from http://wwwlib.umi.com/dissertations/fullcit/9839049

Bobango, J. C. (1987). The van Hiele levels of geometric thought and student achievement in standard content and proof writing: The effect of phase-based instruction. (Ph.D. Dissertation, The Pennsylvania State University, 1987). UMI Publications.

Breen, J. J. (2000). Achievement of van Hiele level two in geometry thinking by eighth-grade students through the use of geometry computer-based guided instruction. (Ed.D. Dissertation, University of South Dakota, 1999). Dissertation Abstracts International, 60(7), 2415A. Retrieved from http://wwwlib.umi. com/ dissertations/fullcit/9937371

Chew, C. M. (2007). Form one students' learning of solid geometry in a phase-based instructional environment using The Geometer's Sketchpad. Unpublished Doctoral Dissertation, University of Malaya, Malaysia.

Chew, C. M., \& Noraini I. (2007). Assessing form one students' learning of solid geometry in a phase-based instructional environment using The Geometer's Sketchpad. In Noraini Idris (Ed.), Classroom assessment in mathematics education (pp. 103-126). Kuala Lumpur: MacGraw Hill (Malaysia).

Chew, C. M., \& Lim, C. S. (2010). Developing primary pupils' geometric thinking through phase-based instruction using The Geometer's Sketchpad. In Y. Shimuzu, Y. Sekiguchi \& K. Hino (Eds.), Proceedings of the Fifth East Asia Regional Conference on Mathematics Education (EARCOME 5) (Vol. 2, pp. 496-503). Tokyo, Japan: Japan Society of Mathematical Education.

Choi, S. S. (1996). Students' learning of geometry using computer software as a tool: Three case studies. (Ph.D. Dissertation, University of Georgia). UMI Publications.

Choi-Koh, S. S. (1999). A student's learning of geometry using the computer. Journal of Educational Research, 92(5), 301-311. http://dx.doi.org/10.1080/00220679909597611 
Clements, D. H., \& Battista, M. T. (1992). Geometry and spatial reasoning. In D. A. Grouws (Ed.), Handbook of research on mathematics teaching and learning (pp. 420-464). New York: MacMillan Publishing Co.

Dye, J. G. F. (1991). The effect of kindergarten children's use of regular polygonal construction materials on their thinking about two- and three-dimensional geometric figures. (Ph.D. Dissertation, The University of Mississippi, 1990). Dissertation Abstracts International, 52(2), 454A. Retrieved from http://wwwlib.umi.com/dissertations/fullcit/9120282

Fuys, D., \& Geddes, D. (1984). An investigation of van Hiele levels of thinking in geometry among sixth and ninth grades: Research findings and implications. Paper presented at the $68^{\text {th }}$ Annual Meeting of the American Educational Research Association, New Orleans, LA, 27 April. (ERIC Document Reproduction Service No. ED245 934).

Fuys, D., Geddes, D., Lovett, C., \& Tischler, R. (1988). The van Hiele model of thinking in geometry among adolescents. Journal for Research in Mathematics Education Monograph Number 3. Reston, VA: National Council of Teachers of Mathematics.

Gay, L. R., \& Airasian, P. (2003). Educational research: Competencies for analysis and applications (7th ed.). Upper Saddle River, New Jersey: Merrill Prentice Hall.

Halat, E. (2008). Pre-Service Elementary School and Secondary Mathematics Teachers' Van Hiele Levels and Gender Differences. IUMPST: The Journal. Vol 1. Retrieved from http://www.k-12prep.math.ttu.edu/journal/content knowledge/halat01/article.pdf

Hoffer, A. R., \& Hoffer, S. A. K. (1992). Geometry and visual thinking. In T. R. Post (Ed.), Teaching mathematics in grades K-8: Research-based mathematics (2nd ed., pp. 249-227). Boston: Allyn and Bacon.

Jaimie-Pastor, A. (1995). Contributions to the interpretation and application of the van Hiele model: The teaching of plane isometries. The evaluation of the levels of reasoning. (Ph.D. dissertation, Universitat de Valencia, Spain, 1993). Dissertation Abstracts International, 56(2), 314C. Retrieved from $\mathrm{http}: / /$ wwwlib.umi.com/dissertations/fullcit/f 2419859

Knight, K. C. (2006). An investigation into the change in the van hiele level of understanding geometry of pre-service elementary and secondary mathematics teachers. Unpublished Masters Thesis. University of Main.

Malaysian Ministry of Education Malaysia. (2003a). Integrated curriculum for secondary schools: Curriculum specifications, Mathematics Form 1. Kuala Lumpur: Curriculum Development Centre.

Malaysian Ministry of Education Malaysia. (2003b). Integrated curriculum for secondary schools: Curriculum specifications, Mathematics Form 2. Kuala Lumpur: Curriculum Development Centre.

Malaysian Ministry of Education Malaysia. (2003c). Integrated curriculum for secondary schools: Curriculum specifications, Mathematics Form 3. Kuala Lumpur: Curriculum Development Centre.

Mason, M. M. (1997). The van Hiele model of geometric understanding and mathematically talented students. Journal for the Education of the Gifted, 21(1), 38-53.

Massey, J. E. (1993). The study of a learning situation modeled on the van Hiele theory with emphasis on the vocabulary of the student. (Ph.D. dissertation, The University of Alabama). UMI Publications.

Matthews, N. F. (2005). A comparison of Mira phase-based instruction, textbook instruction, and no instruction on the van Hiele levels of fifth-grade students. (Ed.D. dissertation, Tennessee State University, 2004). Dissertation Abstracts International, 65(8), 2929A. Retrieved from http://wwwlib.umi.com/dissertations/fullcit/3141938

McClendon, M. E. (1990). Application of the van Hiele model in evaluating elementary teachers' understanding of geometric concepts and improving their attitudes toward teaching geometry. (Ph.D. dissertation, University of South Florida, 1990). Dissertation Abstracts International, 51(5), 1539A. Retrieved from http://wwwlib.umi.com/dissertations/fullcit/9024906

Mullis, I. V. S., Martin, M. O., \& Foy, P. (2008). TIMSS 2007 International Mathematics Report. Boston: TIMSS \& PIRLS International Study Center. Retrieved from http://timss.bc.edu/TIMSS2007/PDF/07/T07_M_IR_Chapter3.pdf

National Council of Supervisors of Mathematics. (1977). National Council of Supervisors of Mathematics Position paper on basic skills. Arithmetic Teacher, 25(1), 19-22. 
National Council of Teachers of Mathematics. (1989). Curriculum and evaluation standards for school mathematics. Reston, VA: Author.

National Council of Teachers of Mathematics (NCTM). (2000). Principles and standards for school mathematics. Reston, VA: Author.

Tay, B. L. (2003). A van Hiele-based instruction and its impact on the geometry achievement of Form One students. Unpublished master's dissertation, University of Malaya, Malaysia.

Usiskin, Z. (1982). Van Hiele levels of achievement in secondary school geometry. (Final report of the Cognitive Development and Achievement in Secondary School Geometry Project). Chicago, University of Chicago. (ERIC Document Reproduction Service No. ED 220 288).

van Hiele, P. M. (1959/1984). The child's thought and geometry. In D. Fuys, D. Geddes, \& R. Tischler (Eds.), English translation of selected writings of Dina van Hiele-Geldof and Pierre M. van Hiele (pp. 243-252). Brooklyn, NY: Brooklyn College, School of Education. (ERIC Document Reproduction Service No. 287 697).

van Hiele, P. M. (1986). Structure and insight: A theory of mathematics education. New York: Academic Press.

van Hiele, P. M. (1999). Developing geometric thinking through activities that begin with play. Teaching Children Mathematics, 5(6), 310-316.

van Hiele-Geldof, D. (1959/1984). Last article written by Dina van Hiele-Geldof entitled: Didactics of geometry as learning process for adults. In D. Fuys, D. Geddes, \& R. Tischler (Eds.), English translation of selected writings of Dina van Hiele-Geldof and Pierre M. van Hiele (pp. 215-233). Brooklyn, NY: Brooklyn College, School of Education. (ERIC Document Reproduction Service No. ED 287 697).

Wu, D. B. (1994). A study of the use of the van Hiele model in the teaching of non-Euclidean geometry to prospective elementary school teachers in Taiwan, the Republic of China. (Ph.D. dissertation, University of Northern Colorado, 1994). Dissertation Abstracts International, 55(5), 1215A. Retrieved from http://wwwlib.umi.com/dissertations/fullcit/9427458 